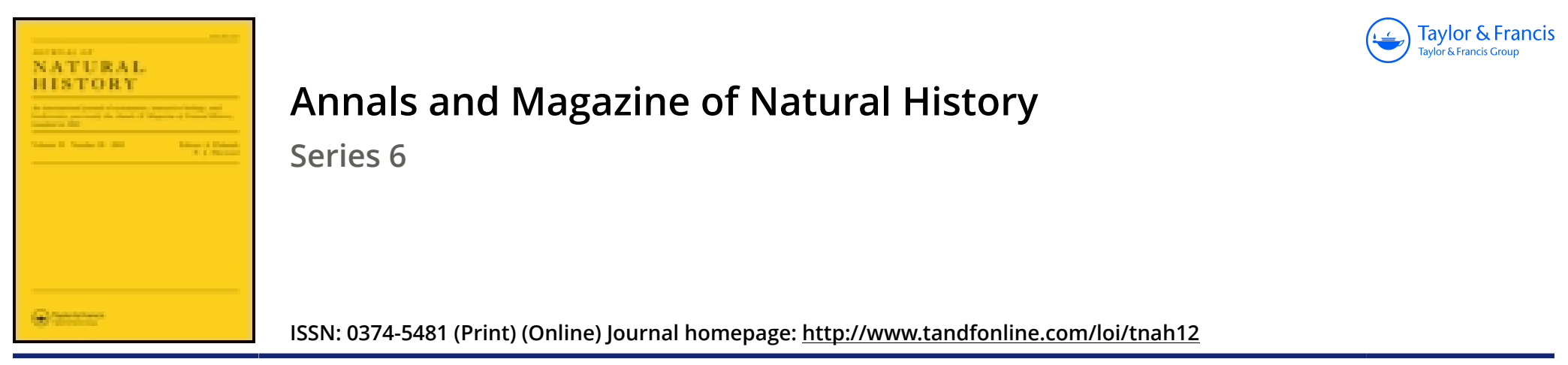

\title{
LXIV.-Descriptions of new Genera and species of Pyralidæ contained in the British-Museum Collection
}

\section{W. Warren M.A. F.E S.}

To cite this article: W. Warren M.A. F.E S. (1892) LXIV.-Descriptions of new Genera and species of Pyralidæ contained in the British-Museum Collection, Annals and Magazine of Natural History, 9:54, 429-442, DOI: 10.1080/00222939208677357

To link to this article: http://dx.doi.org/10.1080/00222939208677357

曲 Published online: 02 Oct 2009.

Submit your article to this journal $\pi$

Џll Article views: 3

Q View related articles $₫$

4 Citing articles: 5 View citing articles 주다. 


\section{LXIV.-Descriptions of new Genera and Species of Pyralidx contained in the British-Museum Collection. By W. Warren, M.A., E.E S.}

[Continued from p. 397.]

\section{Trischistognatha, gen. nov.}

Fore wings elongate; costa straight, slightly and gradually convex at apex, which is blunt; hind margin oblique, hardly curved, with a very slight indentation above the anal angle. Hind wings rounded. Antennæ laminated, a little thicker in male than in female; tongue present; ocelli minute; labial palpi with all three joints very distinct; first and second securiform, the first twice as broad as the second, third shortly rostriform ; maxillary palpi like the third joint of the labial ; abdomen of male with rather long anal tuft; hind tibir with two pairs of spurs, the inner very much longer than the outer; scaling fine and smooth. Wings semidiaphanous; neuration normal.

Type T. palindialis (Spilodes), Guen. Delt. \& Pyr. p. 380.

\section{Tholeria, Hüb.}

Type T. illiberalis, Hüb. Verz. p. 354.

\section{Tholeria stigmosalis, sp. n.}

Fore wings with base, inner and hind margins dull reddish; central area whitish, with the costa, the two stigmata, and the veins round them black-brown; the stigmata themselves filled up with reddish; the white interspaces finely dusted with dark atoms; a faint trace of a curved exterior line at the extremity of the white central space ; fringe dark brown. Hind wings pearly white, with an irregular, narrow, reddishbrown marginal suffusion, which here and there runs up a little way along the veins; fringe white, slightly tinged with reddish towards apex. Head, palpi, antennæ, and thorax dull reddish; abdomen darker brown, with segmental divisions white ; collar fawn-colour, paler than either head or thorax. Underside: fore wings pearly white, tinged with yellowish, with only the hind margin and stigmata reddish. Hind wings like the upperside, but with the costa reddish brown, 
tinged with yellow, and with an ilregular reddish projection from it towards the centre.

Fxpanse of wings 30 millim.

Four males from S. Paolo.

\section{Cirrochrista, Led.}

Type C. oetherialis, Led. W. E. M. vii. p. 441, pl. xvii. fig. 9 .

Cirrochrista margarita, sp. $\mathrm{n}$.

Fore wings satiny white, transparent; costa and hind margin irregularly tawny brown, the former with a triangular projection at one third and a larger one at two thirds; a smaller one between them and another between the first and the base; on the inner margin at one third a tooth-shaped brown marking nearly touches the first larger costal projection; another large projection from the hind margin similarly all but touches the second larger costal one ; apical region occupied by two snow-white spots, the exterior the smaller and separated from the larger one by a fine fulvous line; fringe whitish, tinged with fulvous. Hind wings pure white, with a mixed rosy and yellow narrow hind margin and a narrow rosy stripe running up the wing along the inner margin. Head, thorax, and abdomen white; vertex of head, collar, top of last segment of thorax and of all abdominal segments redbrown; palpi and outside of all tibiæ more or less tinged with brown. Underside yellowish white, with markings of the upperside showing through.

Expanse of wings 24 millim.

Two males from S. Paolo.

\section{Ramila, Moore.}

Type R. marginella, Moore, P. Z. S. 1867, p. 667.

Ramila angustifimbrialis, sp. $\mathrm{n}$.

Pearly white; costa fulvous, the streak thinning out towards the apex; first line appearing only as a very small projection from the costal streak, second line slightly more distinct for a short distance from the costa, and again on the middle of the inner margin; discocellular vein thinly marked with fulvous, but thickening into two dots at the ends; fringe white, fulvous-tinged, with a fulvous basal line, which is itself preceded by a row of almost contiguous darker dashes at the ends of the veins. Hind wing like fore wing, with 
traces of two fine fulvous transverse lines, visible only near the inner margin. Abdomen, underside, middle and hind legs white; palpi, sides of thorax level with the costal streak of fore wing, and fore tibia fulvous.

Expanse of wings 22 millim.

One female from Burmah.

\section{Phlyctania, Hüb. \\ Type $P$. sambucalis (Schiff.), Hüb. Verz. p. 359. \\ Phlyctcenıa ferruginealis, sp. $\mathrm{n}$.}

Fore wings fuscous cinereous, coarsely scaled; the markings nearly all obliterated; the paler ground-colour showing only as faint yellowish patches towards the middle of the first and second lines. Hind wings whitish ochreous, partially suffused with fuscous, especially towards the hind margin, and with a curved submarginal line. Underside paler.

The markings of the fore wings are the same as in $P$. arenacea, of which species it is not improbable that it may turn out to be the male.

Expanse of wings 24 millim.

One male from Rio Janeiro.

\section{Phlyctonia paolinalis, sp. $\mathrm{n}$.}

Fore wings yellowish ochreous, inclining to orange, finely dusted with fuscous; basal half of costa fuscous; first line bent, or even angulated externally, in the middle; second sinuous, not denticulate; submarginal denticulate, fairly distinct; fringe with darker basal and medial line; stigmata distinct. Hind wings yellowish white, with a distinct, submarginal, curved line and fuscous shade before fringe. Head, thorax, and abdomen yellowish ochreous. Underside dull ochreous, with few markings.

Expanse of wings 20 millim.

One female, four males, from S. Paolo and Rio Janeiro.

\section{Phlyctonia arenacea, sp. $\mathrm{n}$.}

Fore wings pale sandy ochreous, dusted with darker; first line wavy, nearly vertical, at one third; second sinuous and denticulate, forming a moderate sinus in middle; faint traces of a submarginal darker line ; fringe glossy, with a darker medial line; stigmata indistinct; orbicular dot-like; reniform lunate. Hind wings white, with basal and medial line 
of fringes fuscous ; an indistinct trace of an abbreviated submarginal line. Underside dull ochreous, with darker suffusion; external line of both wings distinct; veins of fore wings dark. Head, thorax, and abdomen all sandy ochreous.

Expanse of wings 24 millim.

Four females from Theresopolis, Rio Janeiro, and S. Paolo.

\section{Hyaloplaga, gen. nov.}

Distinguished from Phlyctcenia, which in shape and appearance it much resembles, by several structural differences. Labial palpi not rostriform, but bluntly triangular, slightly porrected upwards. In the male the hind wings have a very prominent shoulder near the base. Fore wings with the submedian nervure somewhat distorted, curved downwards towards the interno-median fold, and with a small tuft of hairs on the upper surface near the base. Antennæ thick, laminated and downy beneath. Female with normal wings. p. 90 .

Type H. pulchralis (Hydrocampa), Moore, P. Z. S. 1867,

\section{LOXOCREON, gen. nov.}

Fore wings elongate ; costa straight, hind margin obliquely curved. Hind wings rounded, slightly indented beneath apex. Labial palpi broad, triangular, porrect; maxillary palpi short, erect; tongue and ocelli present; eyes large; patagia of male prolonged, as in Omiodes, but not to nearly the same extent; abdomen stoutish, of the male prolonged. Wings smoothly and thickly scaled, with oblique markings.

Type L. continuatalis, Wllngrn. (Salbia).

An isolated group peculiar to the Sandwich Islands, but certainly not Omiodes, as Mr. Meyrick makes them.

\section{A vtocosmia, gein. nov.}

Fore wing with straight costa, deflexed only just before the apex, which is produced, but not acutely; hind margin straight, oblique. Labial palpi porrect, rather long; maxillary upright, small; tongue developed; ocelli present; antennæ (female) simple; forehead conically projecting; hind legs with onter spurs peculiarly short; scaling smooth; the veins all finely delineated in white.

Type $A$. concinna, Warr.

The only species, from N.W. America, is separated from Casmocreon by its conical, not rounded forehead, the smoothness of the scaling, and the peculiar neatness of the markings. 


\section{Autocosmia concinna, sp. n.}

Fore wing sienna-brown, with the costa to beyond middle broadly smooth chestnut, which colour also reaches the inner margin at the base; the edges of the two stigmata, the median nervure, the second and third median nervules as far as the second line, the submedian, with an oblique streak running into it from the median below the orbicular stigma, the interno-median vein, the sinuous second line, a line before the dark base of the fringe, and one on each side of the head, all delicately and concisely snow-white; fringes themselves brown-grey, with darker central line; between the middle of the second line and the white hind marginal line is a small undefined greyish-white patch. Hind wings brownish fuscous, without markings. Underside the same, with the second line showing white in both wings. Abdomen fuscous; head, thorax, and outside of labial palpi chestnut-brown; legs and underside of abdomen whitish.

Expanse of wings 15 millim.

\section{Cosmocreon, gen. nov.}

Fore wings elongate, narrow at base, widening considerably towards hind margin; costa straight, convex only just before apex, which is blunt; hind margin simply curved; inner margin bulging slightly near the base. Hind wings rounded, twice as broad as fore wings. Labial palpi porrect, rostriform, rather roughly scaled; maxillary small, nearly upright, broad at apex ; tongue long; ocelli present ; antennæ pubescent in male; forehead with a rounded protuberance; thorax and abdomen rather stout.

Type B. albiceralis, Grote, Bull. U. S. Geol. Surv. iv. p. 678.

The genus will also include $B$. allectalis, Grote.

\section{Euergestis, Hüb.}

Type E. extimalis, Scop. (E. margaritalis, Hüb. Verz. p. 354).

Euergestis consimilis, sp. n.

Closely allied to $E$. extimalis, but distinguished by the much darker tint of the marginal blotch and fringes and by the outer line itself, which, instead of being composed of separate dots, forms a distinct and, near the costa, serrated line.

One specimen, from the Grote Collection. Ann. \& Mag. N. Hist. Ser, 6. Vol. ix. 
Mesographe, Hüb.

Type M. straminalis, Hüb. (M. stramentalis, Hüb. Verz. p. 354).

\section{Mesographe junctalis, sp. $\mathrm{n}$.}

Fore wings straw-colour, with the basal third and the hind margin broadly bronzy fuscous; the fuscous tinge of the basal area extends further along the costa and inner margin, so that its outer edge is concave; reniform stigma filled up with fuscous, connected above with the dark costa and obliquely below with the marginal band; fringes fuscous. Hind wings straw-colour, with the same margin as fore wings and a broadish fuscous-grey inner edge. Head, thorax, and abdomen bronzy fuscous, the latter ringed with paler. Underside like upper, but less distinctly coloured.

Expanse of wings 24 millim.

One male from Japan.

Akin to $M$. limbata, but slightly smaller and darker.

A nomostictis, gen. nov.

Diastictis (Hüb. Verz. p. 355), of which the type is argyralis (Huib. Zutr. figs. 113, 114), cannot stand, as it was already employed by Hübner himself at p. 288 of the 'Verzeichniss' for a genus of Geometræ, with artesiaria, Schiff., for type.

I propose to substitute the above term for Diastictis, to include argyralis, Hüb., fracturalis, Zell., and ccecalis, Warr.

Anomostictis coccalis, sp. n.

Fore wings dull fuscous, sometimes with a suffusion of fulvous, slightly paler on the inner side of the exterior line; lines and stigmata very obscure; first line hardly distinguishable at all, owing to the deeper suffusion near the base; exterior line rectangularly sinuous, forming a distinct sinus outwards in the middle and a smaller curve inwards above and below it; reniform stigma a dark dot. Hind wings slightly paler, more fulvous, and darker towards hind margin, with the exterior line of fore wings reproduced. Head, thorax, and abdomen very dark fuscous. Underside slightly paler, with the markings also indistinct.

Expanse of wings 18-24 millim.

One female, two males, from California. males.

The single female is intermediate in size between the two 


\section{Cornifrons, Led.}

Type C. ulceratalis, Led. W. E. M. 1858, p. 147, pl. iv.

Cornifrons pulveralis, sp. n.

Fore wings whitish, coarsely and thickly dusted with greyish ochreous; first line at fully one third, somewhat obscure towards the costa, forming a small tooth outwards on the median vein, then running obliquely basewards, and ending in a dark spot on inner margin; second line from costa at four fifths, dark grey, minutely denticulate, curving inwards at the middle, and thence running parallel to first line; reniform stigma dark grey; space between second line and hind margin clouded with dark grey, with indications of a paler submarginal line; fringes chequered. Hind wings whitish grey, with a dark curved submarginal line, beyond the middle of which is a paler patch. Head and thorax cinereous; abdomen paler. Underside dull grey, with indistinct markings.

Expanse of wings 26 millim.

One male, one female, from Nevada, N. America.

Acharana, Moore.

Type A. otreusalis, Wlk., Moore, Ceyl. iii. p. 285.

\section{Acharana rudis, sp. $\mathrm{n}$.}

Like Pachyzancla stultalis, but larger and more roughly scaled; more suffused with pale greyish fuscous over both wings; costa darker; abdomen pale ochreous grey.

One female, two males, from Japan.

\section{Acharana minoralis, sp. n.}

Fore wing glossy greyish fuscous; the lines still darker; first line slightly oblique, second curving obliquely outwards for two thirds of the wing, then running inwards to beneath the reniform, thence straight to the inner margin; reniform stigma a white lunule. Hind wing like fore wing, but without the white spot. Abdomen glossy grey, with the segmental divisions white.

Expanse of wings 16 millim.

One female from Accra.

\section{Acharana maledicta, sp. $\mathrm{n}$.}

Fore wings dark fuscous cinereous, darker towards costa and hind margin; exterior line forming a distinct three$33^{*}$ 
toothed projection below the middle of the wing; first line preceded and second line followed by a distinct pale space; stigmata black, distinct. Hind wings with the exterior line of fore wings reproduced. Head and thorax dark fuscous; abdomen paler, ochreous. Underside duller and paler, with the markings clearer.

Expanse of wings 20 millim.

One female from Pitcairn's Island.

Acharana descripta, sp. n.

Extremely like Pachyzancla stultalis, Wlk., but smaller, and with the hind margin of the hind wings nearly straight, not rounded.

One female from S. Paolo.

\section{Acharana simplex, sp. n.}

Fore wings clear pale ochreous, with the two stigmata and transverse lines neatly marked, fuscous, and a dark line at base of fringes. Hind wings with discal dot and line distinct. Head, thorax, and abdomen concolorous. Very much like verminalis, Guen., from Sierra Leone, but with the hind margin more oblique and the second line hardly forming a sinus outwards in the middle of the wing.

Expanse of wings 20 millim.

Two males from Bombay.

\section{Acharana olivescens, sp. n.}

Fore wings dull bronzy fuscous olive, with a purple tinge towards the costa, and deeper fuscous towards the hind margin; the lines indistinct, exterior denticulate and slightly edged with paler; a distinct dark discal spot in both wings.

Expanse of wings 28 millim.

One female, one male, from Ecuador.

\section{Acharana indistincta, sp. n.}

Both wings entirely dull dark fuscous, the lines and stigmata only just visible. Hind wings rather darker than fore wings; fringe of hind wings sometimes whitish. Abdomen dark fuscous, with white segmental divisions; anal tuft of the male blackish.

Expanse of wings 30 millim.

Two males, two females, from Japan.

Near A. tristrialis, Bremer, but larger and much darker. 


\section{Acharana elongalis, sp. n.}

Fore wings fuscous, with a purplish tinge, rather glossy. Hind wings darker; all the lines very indistinct; a distinct black discal spot in each wing, which in the fore wing is preceded by a smaller more obscure one; fringes glossy, concolorous. Head and thorax dark fuscous; abdomen paler, somewhat ochreous.

Expanse of wings 28 millim.

One male from Formosa.

The species may be distinguished at once by the elongated fore wings, so much narrower than the rest of the group. In this respect it resembles Stenomeles agavealis, Wlk., but the hind wings are broad and well rounded.

\section{Acharana fuscescens, sp. n.}

Like $A$.rudis, Warr., but larger ; dark fuscous cinereous, generally slightly paler beyond the lines; abdomen dark fuscous.

Expanse of wings 28 millim.

Three examples from Japan.

\section{Stenomeles, gen. nov.}

Fore wings elongate, narrow, quite four times as long as wide; costa straight, very gradually convex before apex; hind margin very oblique. Hind wings triangular, twice as long as broad, with the hind margin nearly straight from inner to anal angle. Palpi as in Acharana; antennæ long, in the male pubescent; collar and patagia clothed with coarse loose scales; abdomen in both sexes long, reaching beyond the hind wings.

Type S. agavealis (Botys), Wlk. xviii. p. 575.

\section{Prionopaltis, gen. nov.}

Fore wings broadish; costa convex before apex; hind margin faintly sinuous, being slightly incurved below apex and elbowed above the anal angle; scaling fine, glossy. Labial palpi broad, porrect, as in Acharana; maxillary erect, behind the labial, rather broad at apex; tongue present; ocelli large; antennæ with angular joints, which in the male project like the teeth of a saw.

Type P. sericea, Warr. 


\section{Prionopaltis sericea, sp. n.}

Fore wing glossy fuscous, rather broader than is usual in the genus; first line very indistinct, slightly oblique, second line also indistinct, bounded below the costa, from which it starts vertically, by a pale yellowish-white blotch, beneath which its middle third shows three distinct teeth, and the lower third one larger tooth; fringes concolorous, with a fine pale line along their base; stigmata darker, but indistinct; the orbicular small, close to the first line; the reniform larger, in the middle of the wing. Hind wing with the second line repeated, and followed by a pale space throughout its course. Ilead, thorax, and abdomen all fuscous.

Expanse of wings 24 millim.

Three females from Dharmsala.

\section{Prionopaltis consocia, $\mathrm{sp} . \mathrm{n}$.}

Fore wings not quite so broad as in $P$. sericea; the costa straighter towards the apex; silky brown, as in sericea, from which it is distinguished as follows: the pale subcostal patch at the beginning of the second line is larger, more distinctly tridentate behind; the end of the line on the inner margin is distinctly marked as a small angulated blotch; the base of the reniform stigma is marked by a minute yellowish dot; all the fringes concolorous, without the bright pale basal line of sericea.

Expanse of wings 26 millim.

One male from. Japan.

\section{Prionopaltis (?) suffusalis, sp. n.}

Fore wing fuscous brown; the lines the same colour, indicated only by a few yellowish dots, which follow their course; a small yellow spot before the orbicular stigma; a square blotch between the two stigmata, and a large, irregular, oval one between the reniform and the second line; below the median vein is a wedge-shaped yellowish mark between the first median nervule and the median vein itself, and below it a square blotch. Hind wing with the second line more visible; a large brown central spot, connected by a second with the outer line; central space irregularly yellow; fringes concolorous.

Expanse of wings 28 millim.

One fornale from Japan. 


\section{Rhectocraspeda, gen. nov.}

Characterized by the hind wing (of the male), which is peculiarly contorted beneath at the anal angle opposite veins $1 a-1 c$, and bears on either side of the contortion a curled wisp of hairs. Fore wing with costa slightly concave in the middle, strongly curved before apex, which is blunt; hind margin obliquely curved. Hind wing with a decided inflection below apex as well as contorted at anal angle. Labial palpi shortly porrect, broad; maxillary invisible; tongue present; antennæ visibly pubescent beneath, each joint with a short spine; ocelli present.

Type R. periusalis (Botys), Wlk. xviii. p. 564.

\section{Camptomastix, gen. nov.}

Fore wing with gradually convex costa, slightly curved, not very oblique hind margin; not more than twice as long as broad. Hind wing by comparison narrow. Labial palpi very long, porrect and thin, third joint half as long as second; maxillary absent; tongue present; oceHli large and conspicuous; antennæ (of male) with enlarged basal joint, finely ciliated throughout, suddenly bent under at one third, flattened and broadened at the curve, which is laterally serrated and bears longer silky hairs, thence thinning out towards the apex. Central field of fore wing clothed with lengthened raised hairs.

Type C. pacalis (Botys), Leech, $q$, = Diplotyla longipalpis, Butler, $\sigma^{\circ}$.

Meyrick's genus Diplotyla has upright palpi.

Agrammia, Guen.

Type A. matronalis, Guen. Delt. \& Pyr. p. 406.

Agrammia cervinalis, sp. n.

Fore wing and thorax fawn-colour; costa whitish. Head and palpi luteous. Hind wings white, with darker fringes. Abdomen fawn-colour.

Expanse of wings 26 millim.

Two males from S. Paolo.

Agrammia lutenlis, sp. n.

Head, thorax, palpi, antennæ, and fore wings bright 
luteous, without markings. Hind wings pale straw-colour, yellower towards the hind margin. Underside paler yellow.

Expanse of wings 24 millim.

A pair from S. Paolo.

\section{Choristostigma, gen. nov.}

Fore wings elongate; costa straight, but before apex rather strongly convex; apex somewhat produced; hind margin oblique, slightly sinuous. Hind wings rounded. Labial palpi horizontally porrect, rostriform; maxillary small; tongue and ocelli present; antennæ of female simply filiform, of male short, thick, laminated, curved backward over the head; forehead slightly produced and rough-scaled; scaling fine and thick, but not glossy; markings, two lines and stigmata, the latter remote from each other.

Type C. plumbosignata (Botys), Fernald, Ent. Am. iv. p. 37, superficially reminding one of Syllythria, but at once distinguished by the structure of the antennæ.

\section{Choristostigma elegantalis, sp. $\mathrm{n}$.}

Fore wing pale yellow, with tawny markings; costa suffused with tawny along basal half; first line indistinct, brown; second line brown, rising nearer hind margin than usual, runs parallel to it as far as the second median nervule, then curves upwards and inwards, touching the base of the reniform stigma, and running along the median nervure nearly to the orbicular stigma, finally reaches the inner margin at about the middle; a submarginal brown shade runs parallel to it, touches it at the elbow, and then forms apparently with its lower portion a continuation of the reniform stigma; all the nervules brownish towards the hind margin, with brown dots at their extremities; orbicular stigma a flattened oval ringed with brown and filled up with groundcolour; reniform large, constricted in middle, edged with brown, and filled up with lilac-grey. Hind wing yellowish white, with dark central spot and faint traces of a curved submarginal band. Underside yellowish, dusted with fascous; all the markings clearer.

Expanse of wings 20 millim.

Two males from California.

Mimudea, gen, nov.

Fore wing elongate, pointed; costa straight; hind margin obliquely sinuous. Labial palpi long, porrect; second joint 
rough-haired above, straight beneath; terminal joint small, smooth, rounded; maxillary palpi erect, small; antennæ laminated, short, curved, with serrate joints, slightly pubescent beneath in male; tongue slight; ocelli present. Female larger and paler than male; male with a distinct anal tuft. Markings, two transverse lines and two stigmata, the latter separated by a pale discal spot; the reniform also followed by a large subcostal pale blotch.

Type M. olivalis, Warr.

\section{Mimudea olivalis, sp. n.}

Fore wing (female) olive-yellowish, suffused with olivefuscous; costa, the two transverse lines and the two stigmata darker fuscous; first line slight, curved, second broader, especially in its lower half, where it becomes a broad shade and unites with the reniform stigma; a small straw-yellow spot before and a larger one beyond the reniform stigma. Hind wing olive-fuscous, paler at base, with a dull central band and row of dark marginal dots.

Male smaller, fuscous grey, without any yellowish tinge, and the pale spots whitish; the central space between the two lines wholly dark fuscous.

Expanse of wings, +16 , o 14 millim.

Two females, two males, from S. Paolo.

\section{Mimudea flavinotata, sp. $\mathrm{n}$.}

Male.-Fore wing cinereous fuscous, the two lines only faintly discernible, the second preceded on costa by a large straw-coloured spot; a smaller round one standing on the disk between the two stigmata, which are scarcely otherwise discernible. Hind wing dull ochreous, with darker hind margin and faint central line.

Female yellowish, very similar to the female of $M$. olivalis, but without the fuscous-olive suffusion, and larger.

Expanse of wings 18 millim.

One female, one male, from Rio Janeiro.

\section{Mimudea subrosea, sp. n.}

Fore wings dull rosy grey; first line fuscous, at one third, nearly vertical; second line from two thirds of the costa, where it is preceded by a large irregularly triangular yellow spot, ending as a vertical line near the centre of the inner margin, approximate and parallel to the first line; a pale yellow spot between the stigmata, which are scarcely 
discernible; fringe yellowish. Hind wings fuscous, with yellowish fringes. Head, thorax, and abdomen rosy grey; anal segment of abdomen yellow.

Expanse of wings 12 millim.

One female, S. Paolo.

In the specimen above described the abdomen is unusually short and apparently malformed.

\section{Pachyzancla, Meyr.}

Type P. stultalis, Wlk. (P. mutualis, Meyr. Tr. E. S. 1884, p. 315 (part)).

Pachyzancla dissimilis, sp. n.

Resembles stultalis, Wlk., but smaller, the transverse lines not preceded or followed by a paler space; first line less oblique, nearly vertical, second line without any denticulations in the middle and lower thirds; the general groundcolour of both wings more uniformly fuscous.

One female from Accra.

LXV.-Notes on Dr. C. Flach's Synonymic List of the European Trichopterygidæ. By the Rev. A. Matthews.

For the last few years the time which Ihave been able to devote to entomology has been fully occupied in investigating the Corylophidæ; but since that study has been almost finished, I have lately turned my attention to collecting materials for a second part of my 'Trichopterygia Illustrata,' and I find that such a work is much needed, for, since the publication of the first part in 1872, the number of the Trichopterygidæ has been nearly doubled by the discovery of fresh species in various parts of the world, especially in America, through the exertions of Mr. Crotch, Mr. Champion, Dr. Le Conte, Dr. Horn, and Mr. Casey.

Thus it has happened that until a few weeks ago I was unaware of the existence of an important essay on the European species of 'Trichopterygidæ from the pen of Dr. C. Flach, published in the 'Verhandlungen der kaiserlich-königlichen zoologisch-botanischen Gesellschaft in Wien,' vol. xxxix. 1889 , pp. 481-532.

In this essay Dr. Flach has revised, or, rather, attempted 